\title{
IE (Intelligent Electronics) Competition in the Annual Conference of Korean Institute of Power Electronics July 2 - 4, 2019, Resom Spa Castle, Chungcheong - South Korea
}

Korean Institute of Power Electronics (KIPE) の 24 回目の年 次大会が 2019 年 7 月 2 日から 4 日まで韓国忠清南道礼山郡 の Resom Spa Castle で開催され, その恒例の企画の一つと して, 17 回目となる学部学生向けのアイデアコンテスト Intelligent Electronics (IE) Competition が実施された。年次大 会は韓国国内から約 500 人が参加し, 約 300 件弱の論文発 表が行われている。過去 5 年の論文数と参加者数の推移を 表 1 および図 1〜2 に示す。Journal of Power Electronics 誌へ の投稿を促進するセッションを設けるなどテコ入れをして いるようである。IE Competition は, 電気学会と KIPE の交 流を目的として日本の大学の研究室からここ数年毎年参加 している。参加チームは複数の審査委員に対してデモンス トレーションとポスターにより口頭で説明と質疑応答を行 う。評価の結果, 最優秀チームには表彰状と賞金 100 万ウ オン（約 9 万円）が贈られた。

参加チームは原則としてまだ研究室に所属していない 3 年生以下の学部生で, 指導教授のサポートはあるものの多 くの独創的なアイデアと高い実装力がみられた。例えば円 弧状に配置した LED を回転させて球に任意のパターンを表 示させる装置などは印象深かった（図 3）。日本からは, 星

表 1 過去 5 年の論文数と参加者数およびその内訳

\begin{tabular}{|c|c|c|c|c|c|}
\hline & 2015 & 2016 & 2017 & 2018 & 2019 \\
\hline $\begin{array}{l}\text { 投稿論文数 (口頭/ポスタ } \\
\text { ー/JPE) }\end{array}$ & $\begin{array}{l}283 \\
(140 / \\
143)\end{array}$ & $\begin{array}{l}280 \\
(145 / \\
135)\end{array}$ & $\begin{array}{l}256 \\
(123 / \\
133)\end{array}$ & $\begin{array}{l}231 \\
(103 / \\
128)\end{array}$ & $\begin{array}{l}245 \\
(112 / \\
125 / 8)\end{array}$ \\
\hline $\begin{array}{l}\text { 最終論文数 (口頭/ポスタ } \\
\text { ー/JPE) }\end{array}$ & $\begin{array}{l}249 \\
(118 / \\
131)\end{array}$ & $\begin{array}{l}233 \\
(105 / \\
128) \\
\end{array}$ & $\begin{array}{l}234 \\
(108 / \\
126)\end{array}$ & $\begin{array}{c}197 \\
(89 / \\
108) \\
\end{array}$ & $\begin{array}{l}210 \\
(89 / \\
113 / 8)\end{array}$ \\
\hline 取下げ論文数 & 34 & 47 & 22 & 34 & 35 \\
\hline $\begin{array}{l}\text { 全体論文数 (特別セッショ } \\
\text { ン, 産業技術セッション) }\end{array}$ & 305 & 290 & 281 & 243 & 278 \\
\hline 大学 (論文数/登録者数) & $\begin{array}{l}188 / \\
394\end{array}$ & $\begin{array}{l}190 / \\
361\end{array}$ & $\begin{array}{ll}209 / \\
385\end{array}$ & $\begin{array}{l}173 / \\
411\end{array}$ & $\begin{array}{l}175 / \\
357\end{array}$ \\
\hline 研究所 (論文数/登録者数) & $16 / 31$ & $11 / 50$ & $8 / 56$ & $8 / 49$ & $18 / 58$ \\
\hline 産業界 (論文数/登録者数) & $\begin{array}{l}45 / \\
155\end{array}$ & $\begin{array}{l}32 / \\
137 \\
\end{array}$ & $17 / 91$ & $\begin{array}{l}16 / \\
138\end{array}$ & $\begin{array}{l}17 / \\
101\end{array}$ \\
\hline 全登録者数 & 580 & 548 & 532 & 598 & 516 \\
\hline
\end{tabular}

※Journal of Power Electronics 投稿向け SS

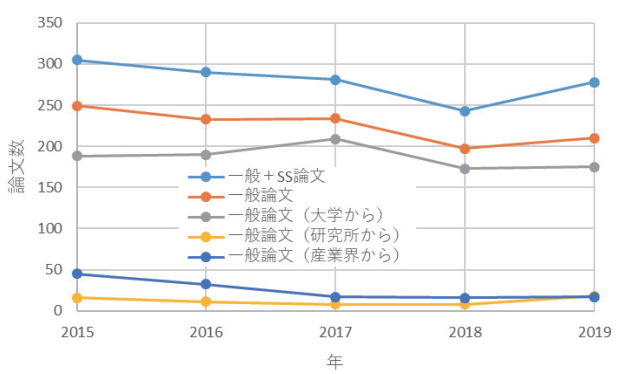

図 1 論文数の推移

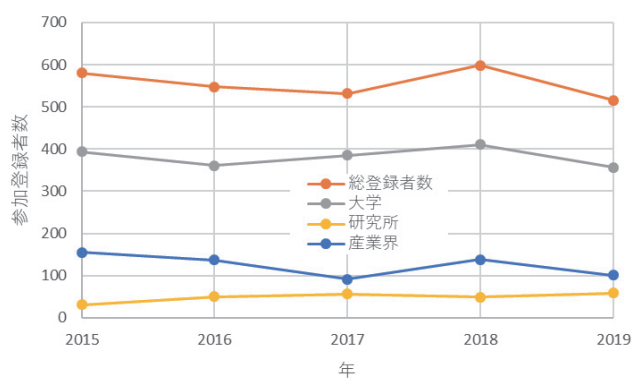

図 2 参加者数の推移

伸一教授引率の東京理科大学が車両の位置推定が可能なワ イヤレス給電システムのデモを, 筆者引率の横浜国立大学 が杖型ロボットのデモを行い, 両チームとも特別賞を受賞 した（図 4, 5)。このようなイベントは電気学会と KIPE の 技術交流にとって重要であるばかりか, 学生が国際感覚を 身に着けるのに大変良い機会であると思われる。

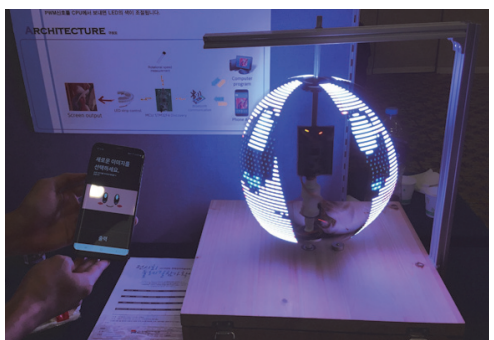

図 3 IE Competition のデモンストレーションの一例

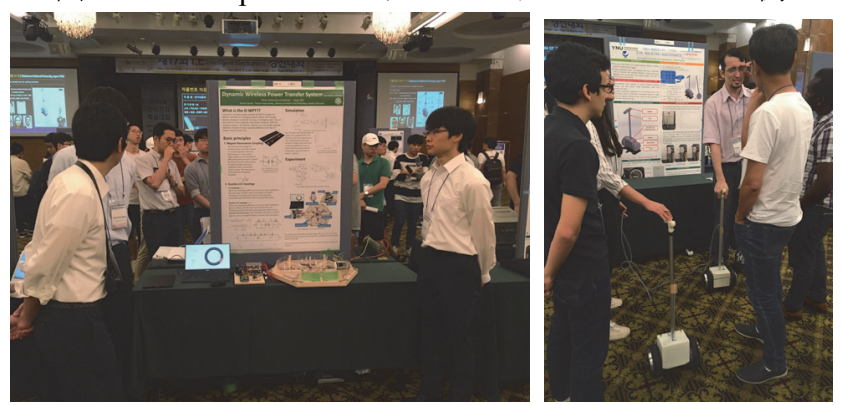

図 4 発表の様子

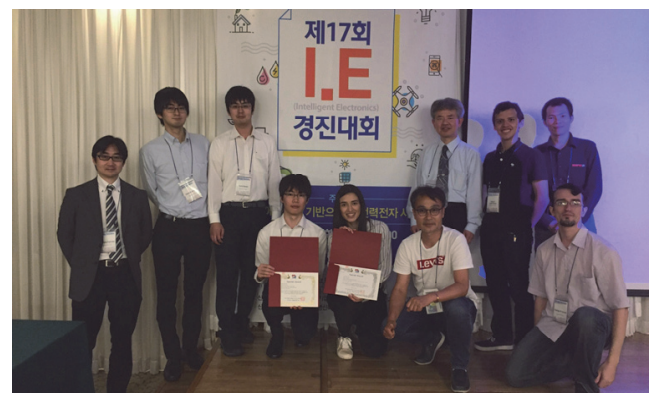

図 5 東京理科大と横浜国大のチーム（金泰雄先生と）

藤本康孝（横浜国立大学） (令和元年 9 月 10 日受付) 